Tabŭla, ae $f$ дошка; $\phi p$. table $f$ cтіл; tableau m дошка (класна), картина; tablette $f$ плитка; tôle $f$ листове залізо; англ. table стіл, tablet дощечка, блокнот; нім. Tafel $f$ дошка, Tabelle f таблиия; укр. табель, табличя, таблетка, толь.

Nomen, іпіs $n$ ім'я; англ. пате, нім. Naте $m$; $\phi p$. поте $m$, renотте́е $f$ слава; noтinal номінальний; англ. потіпаtive називний відмінок; нім. Nominativ m, nominell; укр. номенклатура, номінатив, номен.

Mens, -ntis $f$ розум; думка; фp. -mеnt суфікс прислівників; mental мисленнєвий, англ. mental розумовий, сот-тепt витлумачення; нім. Mentalität $f$ склад розуму; укр. ментальність, менталітет, коментар.

Con-fёro зносити (в одне місие), збирати, порівнювати; фp. conférer радитися, conference $f$ нарада; англ. confer порівнювати, conference; нім. Konferenz $f$ вести переговори; укр. конферениія, конферанс.

Consilium, і п рада, нарада; рішення, план; фр. conseil m, conseiller радити; англ. counsel, counselor радник, адвокат; нім. Konsulent $m$ юрисконсульт, konsultativ раднищький, Konsilium п; укр. консиліум, консультант, консультація.

Запропонована система завдань дозволить розвинути у студентів філологічних спеціальностей індивідуальний професійно когнітивний стиль майбутнього фахівця. Реалізація подібного підходу до навчання дозволяє навчити студентів орієнтуватися в сучасному педагогічному просторі: проектувати педагогічну діяльність у процесі роботи у профільних класах або оперативно змінювати стиль роботи відповідно до модернізації освітніх програм, профілізації старшої школи.

\title{
Література
}

1. Вацеба О. А. Lectura Latina : [навчальний посібник] / Ольга Анатоліївна Вацеба, Любов Рудольфівна Олійник. - Львів : ВЦ ЛНУ імені Івана Франка, 2008. 200 c. 2. Каган Ю. М. Латинский язык. Основной курс для самостоятельного изучения : [учебное пособие] / Юдифь Матфеевна Каган. - М. : Канон +, 2001. - 400 с. 3. Маслюк В. П. Латинська мова / В. П. Маслюк, М. Г. Сенів. - Харків : Основа, 1992. - 314 с. 4. Мушак Ю. Ф. Латинська мова : [підручник для університетів] / Юрій Федорович Мушак. - Львів : ЛДУ, 1964. - 250 с. 5. Оленич Р. М. Латинська мова : підручник [для студентів вищих навчальних закладів] / Роман Михайлович Оленич. Львів : Світ, 2001. - 352 с. 6. Універсальний словник української лексики. Синоніми, антоніми, омоніми / укл. Нечволод Л. І., Бездітко В. І., Паращич В. В. - Х. : Торсінг плюс, 2009. -768 с.

Наталія Мозгальова

\section{МУЗИЧНІ ЗДІБНОСТІ, ЇХ СУТНІСТЬ І РОЗВИТОК У ПРОЦЕСІ ІНСТРУМЕНТАЛЬНО-ВИКОНАВСЬКОЇ ПІДГОТОВКИ ВЧИТЕЛІВ МУЗИКИ}

Мозгальова Н. Г. Музичні здібності, їх сутність і розвиток у процесі інструментально-виконавської підготовки вчителів музики.

У статті розглянуто основні музичні здібності: ладове чуття, музично-слухові уявлення, чуття ритму, музичну пам'ять і музичне мислення. Визначено можливості їх формування в процесі інструментально-виконавської підготовки вчителів музики. 3'ясовано, що музичний слух - це здатність сприймати та усвідомлювати смисл послідовностей i сполучень звуку в музичному творі. Розкрито природу та особливості музичного ритму. Виокремлено види музичної пам'яті (слухо-образну, емоційну, конструктивно-логічну і рухово-моторну), а також основні способи i прийоми успішного запам'ятовування музичного тексту. Визначено загальнонаукову 
методологію процесу музичного мислення; фактори, що впливають на ефективність його формування.

Ключові слова: інструментально-виконавська підготовка, вчитель музики, музичний слух, музичний ритм, музична пам'ять, музичне мислення.

Мозгальова Н. Г. Музыкальные способности, их сущность и развитие в процессе инструментально-исполнительской подготовки учителей музыки.

В статье рассмотрены основные музыкальные способности: ладовое чувство, музыкально-слуховые представления, чувство ритма, музыкальную память и музыкальное мышление. Определены возможности их формирования в процессе инструментально-исполнительской подготовки учителей музыки. Выяснено, что музыкальный слух - это способность воспринимать и осознавать смысл последовательностей и сочетаний звуков в музыкальном произведении. Раскрыта природа и особенности музыкального ритма. Выделены виды музыкальной памяти (слухо-образная, эмоциональная, конструктивно-логическая и двигательно-моторная), а также основные способы и приемы успешного запоминания музыкального текста. Определена методология изучения процесса музыкального мышления; факторы, влияющие на эффективность его формирования.

Ключевые слова: инструментально-исполнительская подготовка, учитель музыки, музыкальный слух, музыкальный ритм, музыкальная память, музыкальное мышление.

Mozhaleva N. G musical abilities, their nature and development during the instrumental music performance teacher training.

In the article the basic musical skills: modal sense, musical and auditory presentation, sense of rhythm, musical memory and musical thinking are considered. The possibility of their formation during instrumental performance training music teachers are defined. It was found that ear for music is an ability to perceive and realize the meaning of sequences and combinations of sounds in music. The article discloses the nature and features of rhythm. The author determined types of musical memory (auditory-shaped, emotional, structural and logical and motor-motor) and the basic methods and techniques of successful remembering music text. The article defines general scientific methodology of musical thought process; factors affecting the efficiency of its formation.

Key words: instrumental performance in training, music teacher, music listening, musical rhythm, musical memory, musical thinking.

Необхідність концептуалізації питань якості інструментально-виконавської підготовки вчителя музики посилюється соціальним замовленням на відповідні інформаційному суспільству цілі, завдання, форми, якість вищої освіти, і передовсім на особистість фахівця, здатного до швидкої, гнучкої зміни своєї життєдіяльності. Це створює об'єктивні умови для перегляду теоретико-методичних основ інструментального навчання у вищій школі, що склалися за останнє сторіччя. Подолання репродуктивного стилю підготовки вчителів музики i перехід до дидактичної парадигми, котра забезпечить пізнавальну активність і професійну креативність студентів $\epsilon$, на наш погляд, одним із стратегічних напрямів підвищення якості навчання гри на музичних інструментах у вищих педагогічних навчальних закладах. У зв'язку з цим актуалізується проблема розвитку музичних здібностей майбутніх учителів музики. Розглядуване питання було предметом розгляду багатьох педагогів і методистів сучасного і минулого, зокрема М. Давидова, С. Майкапар, 
К. Метнера, Г. Нейгауза, В. Сраджев, Г. Ципіна та ін.

Mema cmammi- обгрунтувати важливість розвитку музичних здібностей майбутніх учителів музики у процесі інструментально-виконавської підготовки у вищих педагогічних навчальних закладах.

Успішність інструментально-виконавської підготовки вчителів музики значною мірою залежить від розвитку музичних здібностей - комплексу природних задатків, необхідних для успішної музичної діяльності. В музичній психології до основних музичних здібностей відносять: ладове чуття (здатність відчувати емоційну виразність звуковистотного руху); музично-слухові уявлення (здатність звуковисотного відображення мелодії); чуття ритму (здатність активного рухового переживання музики, відчуття його відтворення). Крім того, до комплексу музичних здібностей дослідники відносять музичну пам'ять і музичне мислення. Варто наголосити, що розвиток музичних здібностей- це безперервний процес, який охоплює всі стадії музичного розвитку особистості і відповідно всі вікові етапи іiі розвитку. Саме поняття здібності - поняття «динамічне», адже «ніщо у сфері вищої нервової діяльності не залишається нерухомим, статичним, всього можна досягнути, змінити на краще, аби тільки були створені відповідні умови» (І. Павлов).

Для того, щоб повніше розкрити сутність вищеозначеної проблеми спрямуємо увагу на визначення поняття «музичний слух». В широкому смислі воно означає здатність сприймати та усвідомлювати смисл послідовностей і сполучень звуку в музичному творі. У своїх роботах Б.Теплов робить важливий висновок: «музичнослуховий процес розгортається за тими законами, яким підпорядковується будь-який пізнавальний акт. Його специфіка може бути пов'язана 3 особливостями звукової організації музики як об'єктивного явища» [5]. В зв'язку з цим у музичній практиці розрізняють такі види музичного слуху, як мелодійний і гармонійний. абсолютний, поліфонічний, тембровий, інтонаційний, поліритмічний, динамічний слух. За визначенням науковців музичний слух це:

- здатність уявляти музику в свідомості, внутрішньо слухати і переживати, не виконуючи і реально іiі не слухаючи (відтворюючи музику в пам'яті, читаючи ноти або створюючи її в процесі творчості) (Ю. Блучевський);

- здатність людини сприймати «музичну мову» та усвідомлювати іï образнувиразну сутність, яка грунтується, перш за все, на вмінні розрізняти і відтворювати відносну висоту музичних звуків (Ю. Келдиш, І. Ямпольський);

- відчуття музичної висоти, що виникає в результаті співвідношення між різними звуковими лініями в їх розвитку (Б. Теплов);

- здатність вслуховуватись, порівнювати, оцінювати найбільш яркі засоби музичної виразності (Т. Пчьолкіна);

- здатність сприймати, представляти та емоційно переживати зміст музичного твору у всіх аспектах: звуковисотних, ритмічних, тембрових, динамічних, формоутворюючих тощо (П. Халабузарь, В. Попов).

Багаторічне вивчення типів вищої нервової діяльності дало можливість Б. Теплову дійти висновку, що основними компонентами музичного слуху є слухові уявлення. На його переконання, у відчутті музичного звуку на перший план виступає відносна висота i уявлення, тоді як абсолютна висота i тембр $є$ моментами підпорядкованими, тобто «при засвоєнні певної мелодії людина чує в якійсь мірі іiі абсолютну висоту і тембр які потім відображуються в уявленнях. Відповідно розвиток музичного слуху можна систематизувати і розподілити на такі етапи: перший - розвиток музичного слуху зовнішніми подразниками, тобто спів по слуху. 
На цьому етапі на перший план виходить «зовнішній» слух і зовнішні подразники, приділяється увага внутрішньо слуховим уявленням. На другому етапі внутрішньослуховим уявленням надається більше уваги, ніж зовнішньо-слуховим. Протягом третього етапу головна увага приділяється внутрішньо-слуховим уявленням, і зокрема «внутрішньому слуху». Отже «нормальний хід розвитку музичного слуху, - на думку вченого,- передбачає одночасний розвиток i його складових «зовнішнього i «внутрішнього», тобто музично слухових уявлень».

Розвиток темброво-слухових уявлень здійснюється за подібним алгоритмом: «вихідні музичні уявлення, що виникають на перших спробах відтворення голосом мелодії є узагальненими і далекими від дійсності. Потім засвоюється звуковисотність i після цього - тембр. Темброво-слухові уявлення виникають і розвиваються не самі по собі, а лише в систематичному і послідовному процесі діяльності» [3, с. 241, 283]. Тому, основним завданням педагога в інструментальному класі на початковому етапі навчання $\epsilon$ вироблення швидкої орієнтації у висотних, тимчасових, силових, тембрових співвідношеннях звуків, розвиток ритмічного, тембрового і ладового відчуття, збагачення пам'яті новими музичними уявленнями. Крім того, пі час формування темброво-слухових уявлень необхідно зважати на розвиток внутрішньослухових, інтервально-ступеневих, метро-ритмічних, інтонаційно-образних та асоціативних уявлень без яких неможливо досягнути високого рівня виконавської майстерності та досягти успіху у професійній діяльності [3, с. 43, 49].

Для розвитку темброво-слухових уявлень велике значення має здатність до усвідомлення звучань гармонічних функцій. Це підтверджується відомим висловлюванням Ф.Блюменфільда, який вимагав від своїх учнів вміння...так «запам'ятати слухом гармонізацію, щоб зуміти, якщо, постане необхідність, 3 достатньою легкістю відтворити без акомпанементу мелодію, спираючись лише на слухову пам'ять. Або озвучити мелодію з іншою гармонічною фактурою». Ця навичка $\epsilon$ особливо важливою і необхідною для студентів педагогічних вузів, адже в процесі своєї професійної діяльності вони стикатимуться 3 необхідністю показу і виконання твору в різних тональностях, регістрах, під авторський супровід або власний акомпанемент.

Здатність до довільних, керованих темброво-слухових уявлень, розвиваючись та удосконалюючись, створює умови для їх перетворення із репродуктивних в нові, створені творчою фантазією, художні утворення. За твердженням А.Віцинського, дійсне художнє виконання стає можливим лише тоді, коли вдається « ..вийти 3 уявлень конкретного звучання та уловити в уявленні ті виразні потенції, які в «скритому» вигляді вміщуються у творі і які ... не можуть знайти повного і точного відображення в нотному запису [2, с. 184]. Саме такі темброво-слухові уявлення, на думку дослідника, повинні стати основою для формування найбільш раціональних виконавських дій. Тому, багато видатних педагогів вважали орієнтацію на створення яскравого виконавського образу первинним етапом формування виконавських навичок.

Одним з найбільш важливих і складних завдань музичної педагогіки є виховання чуття ритму. Ритм є одним із головних елементів музики, що обумовлює ту або іншу закономірність в організації звуків у часі. При цьому, проводячи аналогії між ритмом в музиці та в інших мистецтвах, музикознавці наголошують на умовності використання цього терміну і відзначають особливу специфічність музичного ритму. Будучи одним із «першоелементів» музики, іiі виразним засобом, ритм відображує емоційний зміст музики, іiі образно-поетичну сутність. На образно-поетичному, художньо-смисловому аспекті музичного ритму наголошують К. Метнер, В. Сраджев, 
Б. Теплов, Г. Ципін. Поряд 3 мелосом і гармонією ритм бере активну участь у створенні емоційного настрою музики, іï змісту. Що ж стосується динаміки, вияву емоцій, творчої активності, енергетичної напруги - тут ритм виконує головну роль. Особливо це відчувається у процесі виконання музичних творів, коли необхідно розкрити композиторський задум, образну насиченість, власні переживання. Тому, художньо-змістовне виконання музики створює передумови для виховання і розвитку музично-ритмічного чуття, яке на думку Б. Теплова $є$ «здатністю активно переживати музику i внаслідок того тонко відчувати емоційну виразність часового ходу музичного руху» [7]. Розвиваючи чуття ритму, необхідно звернути увагу на темпоритм (музична пульсація), ритмічне фразування (відчуття смислової одиниці в ритмічній організації музики), здатність відчувати свободу музично-ритмічного руху (рубато, агогіка), а також відчуття паузи (фактор величезного художнього значення). Отже, система музично-ритмічного виховання майбутніх учителів музики повинна враховувати специфіку навчання гри на музичних інструментах.

Поряд із розвитком музичного слуху і ритму до першочергових завдань музичної педагогіки входить розвиток музичної пам'яті- один 3 компонентів пізнавальної діяльності музиканта. Музична пам'ять являє собою здатність індивіда до запам'ятовування, збереження в свідомості і відтворення музичного матеріалу. Загальними характеристиками продуктивності процесів пам'яті є обсяг матеріалу, який може запам'ятати людина за певний проміжок часу, швидкість запам'ятовування матеріалу, тривалість збереження матеріалу в пам'яті i готовність до його відтворення. Ці характеристики повністю відповідають музичній пам'яті, яка за своєю структурою є складною і взаємопов'язує різні види пам'яті. Так, виконавець в своїй музичній діяльності спирається на слухо-образну, емоційну, конструктивно-логічну і рухово-моторну пам'ять. Але специфіка музичної діяльності обумовлює превалювання слухо-образного компоненту, оскільки музика - це мистецтво слухових уявлень і слухо-образного сприйняття. Пам'ять музиканта включається в роботу, а відповідно і удосконалюється в різних видах діяльності. Адже «все - починаючи від слухання музики і закінчуючи їі написанням - в тій чи іншій мірі торкається сфери музичної пам'яті... Націленість виконавця на вивчення музичного твору напам'ять, мнемічна спрямованість значної частини його повсякденних трудових зусиль обумовлюють суттєву інтенсифікацію процесів музичної пам'яті, помітно

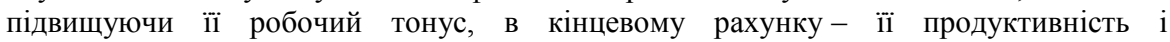
працездатність» [8, с. 103].

На переконання Г. Ципіна механізм функціонування музичної пам'яті полягає у наступному: мислиневе програвання твору живить послідовно розгорнуті в сфері внутрішньо-слухових уявлень звукові образи і картини які згодом отримують відтворення у музичному виконанні. Головною умовою успішного повноцінного запам'ятовування музики є поглиблене розуміння музичного твору, його образнопоетичної суті, особливостей його структури, формоутворення, тобто усвідомлення того, що хотів виразити композитор і як він це зробив. К. Метнер наголошував: «Завжди знати, над чим працюєш, що саме робиш, що маєш на меті, тобто працюючи завжди думати» [4, с. 34].

Аналіз методичних праць і виконавського досвіду відомих майстрів дозволив виокремити основні способи і прийоми успішного запам'ятовування музичного тексту, зокрема:

- при вивченні напам'ять великих творів необхідно рухатись від загального до часткового;

- смислові одиниці (фрагменти, частини) музичного матеріалу, що 
запам’ятовується повинні бути не дуже великими і не дуже малими;

- запам'ятовування музики набагато полегшується при виділенні в тексті так званих опорних пунктів;

- поглибленому розумінню i запам'ятовуванню окремих фрагментів розучуваного твору більшою мірою сприяє мисленнєве зіставлення цих фрагментів 3 відомими, опрацьованими в минулому досвіді;

- одним із специфічних способів вивчення напам'ять $\epsilon$ спосіб «розумовозорового» запам'ятовування, заснований виключно на внутрішньо слухових уявленнях.

Упровадження цих методів у практику інструментально-виконавської підготовки вчителів музики значно підвищить ефективність запам'ятовування музичних творів.

Провідні педагоги і методисти наголошують на необхідності розвитку музичного мислення майбутнього вчителя музики. Більшість вчених вважає музичне мислення складним функціонально-процесуальним комплексом, що містить як розумові, приховані в надрах свідомості і недоступні оточуючим процеси, так i матеріалізовані, призначені для сприймання і доступні вивченню.

Загальнонаукову методологію процесу музичного мислення складають насамперед ключові положення таких провідних концепцій сучасної науки:

- інтонаційної сутності музики (Б. Асаф'єв);

- інтонаційно-фабульної і комунікативної природи музики (В. Медушевський);

- теоретично-інформаційного підхід, де функціонування музичного мислення пов'язується 3 процесами «кодування» i «декодування» художньої інформації, створення унікальної структури тексту (М. Арановський);

- соціальної функції музичного мистецтва (А. Сохор);

- художньо-творчої діяльності як творчого процесу (Є. Назайкінський).

В основі музично-мислительного процесу лежить інтонаційна активність внутрішнього слуху. Мається на увазі визначена Б. Асаф'євим здатність до інтонування і розуміння музики внутрішнім слухом. Завдяки інтонаційній активності внутрішнього слуху забезпечується художньо-образне (інтонаційно-смислове) розкриття музичного твору. Вчений вважає процес інтонування виявленням людського розуму в специфічних формах музичного мистецтва. «Інтонування діяльність людського інтелекту. своєрідна «образно-інтонаційна» форма його мислення [1, с. 147].

Ефективність формування музичного мислення особистості залежить від факторів, які пов'язані зі сферою музичної свідомості індивіда. До таких факторів належать стереотипи музичного сприйняття, сформовані у самого слухача і зумовлені попередніми традиціями та соціально-культурним досвідом особистості; особистісні властивості музиканта, необхідні для розумової діяльності: неупередженість, самостійність думки, сміливість в обстоюванні своїх поглядів, прагнення звести до мінімуму моменти імплицитності й суб'єктивізму, тобто «спираючись на свої смаки, неодмінно розглядати будь-яке музичне явище 3 позицій історизму, який передбачає розуміння форм розвитку музичної і повної традиційності, що склалася, чітких норм, еталонів, жанрів, тощо» [5, с. 25].

Музична діяльність, в якій найпродуктивніше розгортається процес музичного мислення, $є$ культурно-історичною за своєю природою, має особистісний i процесуальні аспекти. Провідним елементом у структурі музичної діяльності як комплексу різних видів діяльності, дій, операцій є особистість - суб'єкт музичної діяльності з його цілеспрямованою пізнавальною активністю. Пізнавальна активність 
майбутнього вчителя музики втілюється в системі цілепокладання, мотивації, чуттєвообразній та інтелектуально-логічній сферах мислення (пізнання, переживання й оцінки), комплексу музично-виконавських знань, вмінь і навичок, особистісної музичної культури, та музично-виконавського досвіду. Внаслідок сприйняття, аналізу та оцінювання музичного втору народжується новий рівень музичного мислення, що стає суттєвим фактором духовного існування особистості.

Підсумовуючи вищесказане, можемо констатувати, що розвиток музичних здібностей $\epsilon$ важливим складнтком інструментально-виконавської підготовки вчителів музики. Це надасть змогу глибоко i всебічно ознайомитись 3 композиторською творчістю представників різних стильових напрямків, творчо переосмислювати авторських задум музичного твору, створювати художньопереконливі виконавські інтерпретації.

До напрямів подальших наукових досліджень можна віднести визначення принципів та обгрунтування педагогічних умов розвитку музичних здібностей, аналіз та створення різних методик удосконалення музичних здібностей.

1. Асафьев Б. Музыкальная форма как процесс / Б. В. Асафьев. Л. Музыка,1971. - 223 с. 2. Вицинский А. В. Психологический анализ процесса роботи пианиста -исполнителя над музыкальным произведением / А. В. Вицинский // Известия АПНРСФСР - Вып 25. - М., 1950. - С. 180-194. 3. Ковалів В. Методика музичного виховання на релятивній основі / В. Я. Ковалів. - К. : Музична Україна, 1973. - 150 с. 4. Метнер К. Н. Повседневная работа пианиста и композитора/ К. Н. Метнер. 5. Проблемы музыкального мышления : [под. ред. М. Арановського].М. : Музыка, 1974. -335 с. 6. Пчелкина Т. Диагностика и развитие музыкальных спрособностей / Т. П. Пчелкина. - М. : Чистые пруды, 2006. - 30 с. 7. Теплов Б. Проблемы индивидуальных различий / Б. Теплов. - M.,1961. - C.116-142. 8. Цыпин Г. Обучение игре на фортепиано / Г. М. Цыпин. - М. : Просвещение, 1984. $-173 \mathrm{c}$.

УдК: 37.01:796.011.3

Евген Павлюк

\section{ПРОБЛЕМНЕ НАВЧАННЯ ЯК ОСНОВА ФАХОВОЇ ПІДГОТОВКИ МАЙБУТНІХ ТРЕНЕРІВ-ВИКЛАДАЧІВ}

Павлюк Є. О. Проблемне навчання як основа фахової підготовки майбутніх тренерів-викладачів.

У статті висвітлено класифікацію теоретико-методичних основ фахової підготовки майбутніх тренерів-викладачів 3 використанням системи проблемних завдань. Конкретизовано загальний зміст теоретико-методичних основ фахової підготовки майбутніх тренерів-викладачів. Важливим пріоритетом фахової підготовки майбутніх тренерів-викладачів $є$ розвиток професійної компетентності, що особливо характерно для студентів старших курсів.

Ключові слова: майбутні тренери-викладачі, фахова підготовка, проблемні завдання, теоретико-методичні основи, класифікація.

Павлюк Е. А. Проблемное обучение как основа профессиональной подготовки будущих тренеров-преподавателей.

В статье представлена классификация теоретико-методических основ профессиональной подготовки будущих тренеров-преподавателей с использованием 